\title{
Origin of Some Transversal Linear Features of NE-SW Trend in Iraq, and Their Geological Characters
}

\author{
Varoujan K. Sissakian1, Nadhir Al-Ansari2 ${ }^{*}$, Sven Knutsson ${ }^{2}$ \\ ${ }^{1}$ Consultant Geologist, Erbil, Iraq \\ ${ }^{2}$ Lulea University of Technology, Lulea, Sweden \\ Email: varoujan49@yahoo.com, ${ }^{*}$ nadhir.alansari@ltu.se, sven.Knutsson@ltu.se
}

Received 16 June 2014; revised 20 July 2014; accepted 2 August 2014

Copyright $@ 2014$ by authors and Scientific Research Publishing Inc.

This work is licensed under the Creative Commons Attribution International License (CC BY). http://creativecommons.org/licenses/by/4.0/

(c) (;)

\begin{abstract}
Iraq is located at the extreme northeastern part of the Arabian Plate, which is in collision with the Eurasian Plate. This collision is still onward, and has caused alignment of the evolved structures in NW-SE trend, mainly, especially in the northern, northeastern and eastern sides of Iraq. However, many transversal linear features of NE-SW trend, represented by rivers, streams, valleys, playas, anticlines and offsets are developed, in parallel trend to the main compressional forces created by the aforementioned collision. Many examples from different parts of Iraq confirm the mechanism of their formation through the geological, geomorphological, tectonics and structural aspects. Although the existing linear features are tens of kilometers in length, but almost no surface displacements were reported, except very few, in some parts of Iraq. The given examples are selected to be the most obvious, when geophysical data are available, the surface and subsurface geology of the involved area is correlated to deduce whether the surface expression coincides with the subsurface or otherwise. A brief tectonic history is also given.
\end{abstract}

\section{Keywords}

Component, Transversal Forms, Playas, Linear Rivers, Streams, Valleys, Plate Collision, Iraq

\section{Introduction}

Iraq forms the utmost northern part of the Arabian Plate. The collision of the Arabian and Eurasian Plates has formed structures of NW-SE trend in most parts of Iraq. These structures are locally dissected by transversal

\footnotetext{
${ }^{*}$ Corresponding author.
}

How to cite this paper: Sissakian, V.K., Al-Ansari, N. and Knutsson, S. (2014) Origin of Some Transversal Linear Features of NE-SW Trend in Iraq, and Their Geological Characters. Natural Science, 6, 996-1011. 
features, which are in NE-SW and ENE-WSW trends, but the former trend is more dominant. These transversal forms are represented by linear geological and geomorphological features, which are tectonically related mostly. Different researchers studied the tectonics of Iraq since the beginning of the twentieth century. Dunnington [1] was among the first researchers to divide Iraq tectonically into three parts (nappe, folded and unfolded zones). These divisions coincide with the physiographic zones of Iraq. Michell [2] encompassed Iraq within two of his first order tectonic divisions of southwest Asia (orthogeosyncline and foreland). Ilhan [3] divided Iraq into Alpine orogenic belt, foredeep and unstable shelf. In 1972, Tikrity and Al-Ani [4] used other three divisions. These were Zagros thrust zone, Mesopotamian Foredeep and the Platform. Recently, according to Fouad [5], Iraq is divided into three main tectonic units; each one has its own characteristics concerning type of the rocks, their age, thickness, and structural evolution. The units are: 1) Inner Platform (Stable Shelf), 2) Outer Platform (Unstable Shelf), and 3) Shalair (Sanandaj-Serjan Zone) Terrane (Figure 1). The first two units of the Arabian Plate lack any kind of metamorphism and volcanism, except within the Zagros Suture Zone. The Arabian Plate is colliding with the Eurasian (Iranian) Plate. This collision has developed a foreland basin, which is called Zagros Fold-Thrust Belt; it includes: 1) Imbricate Zone, 2) High Folded Zone, 3) Low Folded Zone and 4) Mesopotamia Foredeep.
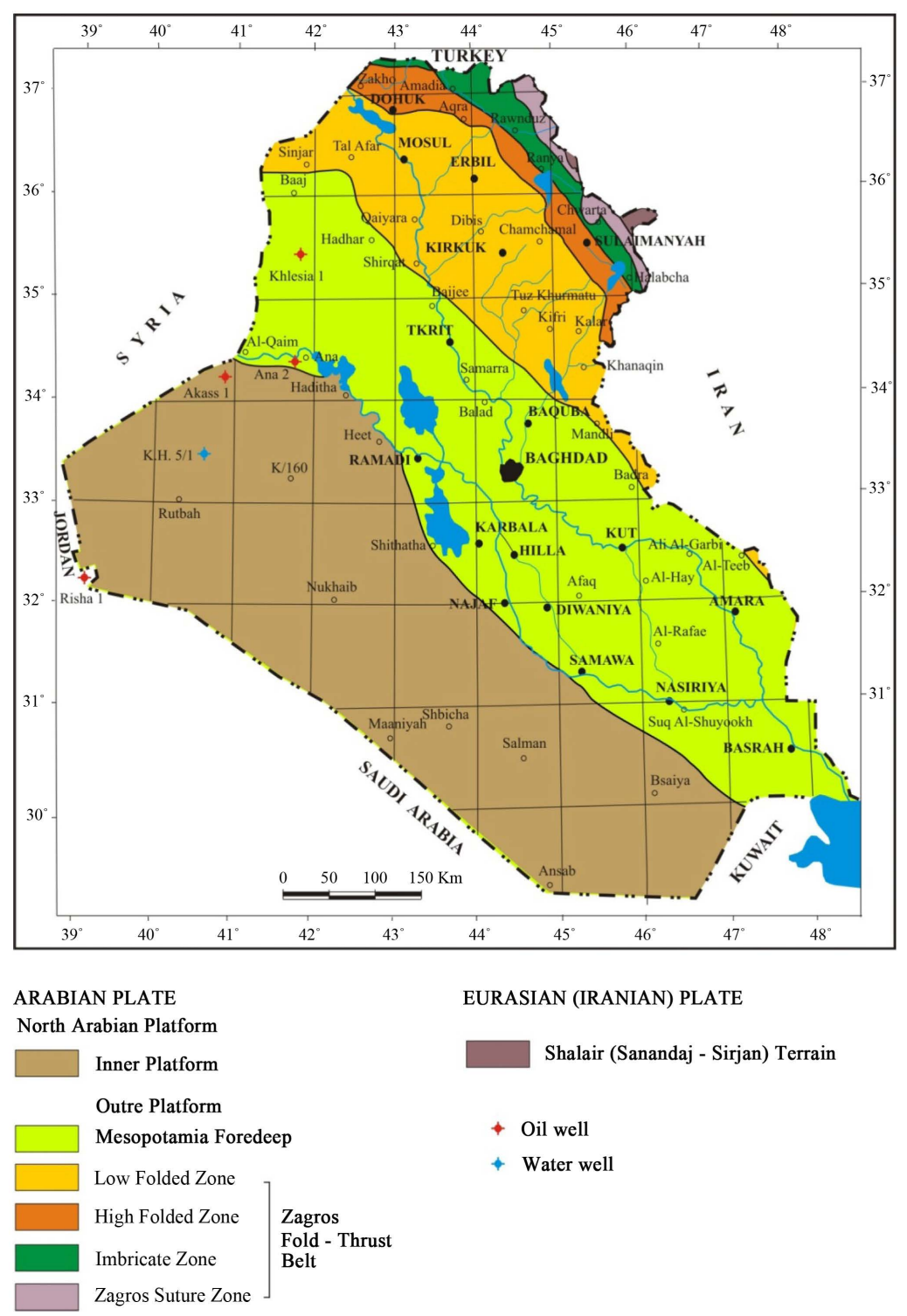

Figure 1. Tectonic frame work of Iraq [5]. 
This study includes the whole Iraqi territory; however, certain examples are selected in different parts of Iraq, to be most obvious and representative. The location of each studied example is shown separately with the geological map of the involved area. The coverage area of each studied site is variable; it is in a range of few hundred square kilometers. The aim of this study is to deduce the most conspicuous linear features with NE-SW trend and to explain the origin of the linear transversal features, which are developed in different parts of Iraq. They have different geological, geomorphological, tectonic and structural characters, with different origins.

\section{Materials Used and Method of Work}

To achieve the aim of this study, the following materials were used:

- Geological maps, at scale of 1:250,000 and 1:1,000,000

- Topographical maps, at scale of 1:100,000 and 1:250,000

- Geological reports concerning this study

- Google Earth, DEM and Satellite images

- Relevant published articles and thesis

The geological and topographical maps with the Google Earth, DEM and Satellite images were used to recognize the present indications about the origin of present linear features. Different geological reports and relevant scientific published articles were reviewed to indicate the indications about the origin of the linear features. Some structural and geophysical data were also reviewed to elucidate the relation between the subsurface geology and the existing linear features.

\section{Previous Work}

There is large number of research carried out in Iraq oriented toward the link between local geological structures and the tectonic framework of Iraq (e.g. Al-Ansari [6], Barazanji and Al-Ansari [7], Gayarah [8]). However, few of the carried out research dealt with the existing linear features in Iraq and were concerned with tectonics and geophysics. These are so old and have used the ex-geosynclinal theory. The most recent and related studies are mentioned hereinafter are:

- Buday [9] mentioned about many transversal deep seated faults, which has NE-SW trend and named them by different geographical names. Many of them coincide with the involved linear features.

- Buday and Jassim [10] presented many deep seated transversal faults with NE-SW trend in the Tectonic Map of Iraq. Majority of them coincide with the existing linear features.

- Al-Kadhimy et al. [11] referred to the transversal deep seated faults; introduced by Buday and Jassim [10] in the Tectonic Map of Iraq, and related them with some geophysical anomalies.

- Jassim and Buday in Jassim and Goff [12] referred to all deep seated faults mentioned by Buday and Jassim [10] and used them in defining tectonic zones of Iraq.

- Fouad and Nasir [13] mentioned the development of the subsurface grabens in the Jazira Plain, which has NE-SW trends.

- Sissakina and Abdul-Jabbar [14] mentioned some linear features with NE-SW trends, including playas, dislocated valleys in the Jazira Plain.

- Sissakian and Abdul-Jabbar [15] mentioned some transversal gorges with NE-SW trends in the northern and northeastern parts of Iraq, and explained their origins.

- Sissakian [16] mentioned subsurface block faults with ENE-WSW trend, which have affected the development of four stages of alluvial fans north of Sinjar anticline, NW Iraq.

- Sissakian [17] mentioned linear features with NE-SW trend in the Jazira Plain, which have affected the evolution of the Tharthar Depression.

- Fouad and Sissakian [18] mentioned some NE-SW linear features in the Mesopotamia Plain and referred them to Neotectonic activities.

- Fouad [5] did not mention the transversal deep seated faults recognized by Buday and Jassim [10] in the Tectonic Map of Iraq.

\section{Tectonic History of Iraq}

The tectonic history of Iraq is related to the plate tectonics movements in the Middle East region. In general, it involves the movement of the Arabian, Eurasian, Iranian and Turkish plates [19]-[25]. Some researchers pro- 
posed that the tectonic forces affected Iraq involved vertical movements of blocks delineated by buried faults and lineaments in the basement [26]-[29]. Henson [30], however, suggested that both types of forces operated in the region; he proposed that vertical forces played an important role before Miocene but the late Tertiary movements were compressional.

A brief tectonic history of Iraq is given hereinafter, based on the available data [5] [10]-[12] [31] [32] to introduce the basics of the tectonic frame work of Iraq.

As mentioned earlier, Iraq is located in the northeastern part of the Arabian Plate; it is divided into three main tectonic units [5]. The units are: 1) Inner Platform (Stable Shelf), 2) Outer Platform (Unstable Shelf), and 3) Shalair (Sanandaj-Serjan Zone) Terrane (Figure 1). The tectonic history of Iraq can be summarized as follow:

\section{- The Inner Platform}

The Inner Platform (Stable Shelf) is less affected by tectonic disturbances; it covers the area south and west of the Euphrates River. The main tectonic feature that had affected the geology is the Rutbah Uplift and with less extent is Ga'ara High. During Oligocene, in the eastern margin of the Inner Platform, the Outer Platform was uplifted causing isolated narrow depositional Oligocene basins. Therefore, very restricted exposures are present in the northern part of the Inner Platform (north of Ga'ara Depression).

During Late Miocene, the continental phase started in Iraq due to the collision of the Arabian Plate with the Sanandaj-Serjan Zone, and no more marine sediments were deposited all over the country.

\section{- The Outer Platform}

It is part of the Arabian Plate, being highly deformed tectonically; it covers the area north and east of the Euphrates River [33]. The Outer Platform includes five zones: 1) Imbricate Zone, 2) High Folded Zone, 3) Low Folded Zone, 4) Zagros Suture Zone, and 5) Mesopotamia Foredeep (Figure 1).

-Imbricate, High Folded and Low Folded Zones: these three zones form the mountainous area in Iraq. They are the most tectonically disturbed part of the Arabian Plate; within the Iraqi territory, because they had received and still receiving (Late Alpine Orogeny) the main stresses released due to the collision of the Arabian and Iranian Plates. The deformation intensity and relief decrease southwest and central wards, therefore, the amplitude of the anticlines decreases in the same direction too. It should be mentioned however that some exceptions exist in many parts of the involved area. The anticlines include the oldest exposed rocks in Iraq, besides the main thrust fault that extends from NE to NW, which forms the tectonic contact between the Imbricate and High Folded Zones. The anticlinal structures in the northeastern part of Iraq have NW-SE trend, which is parallel to the Zagros Fold-Thrust Belt, and extend northwest wards till the Greater Zab River (Figure 1), there they change their trends to E-W.

Many of the anticlines exhibit thrusting along their axial planes, especially in Kirkuk embayment, which had caused over riding of their northeastern limbs over the southwestern limbs. This is attributed, mainly to the presence of thick salt within the Fatha Formation of Middle Miocene age.

-Mesopotamia Foredeep: the Mesopotamia Foredeep extends from northeast Syria to the Straits of Hurmuz. It consists of two domains. The first is a terrestrial one that covers parts of northeast Syria, Iraq, and parts of $\mathrm{Ku}-$ wait and the coastal plains of Iran, and the second is a marine, represented by the Arabian Gulf Basin [13] [31] [34]-[37].

This part, in Iraq includes the Mesopotamia Flood Plain and the Jazira Plain (Area) (Figure 2). It is less tectonically disturbed as compared to the Imbricate, High Folded and Low Folded Zones. It comprises of flat areas; in the southeastern part, forming the flood plains of Tigris and Euphrates rivers with their tributaries and distributaries, the height of the plain decreases towards the southern part until it reaches zero elevation along the Arabian Gulf in the extreme southern part of Iraq.

\section{Main Tectonic Events}

During the early Late Cretaceous (Turonian), supra subduction spreading occurred. During Late Cretaceous (Campanian), obduction of the Neo-Tethyan margin occurred; the synrift sedimentation is represented by the Shiranish Formation, with huge thicknesses; more than $1000 \mathrm{~m}$ [38] were recorded from inverted grabens in many localities, while the deposition of the flysch fine clastics and conglomerate represent the Tanjero Formation.

During the Late Cretaceous, the subsidence of the Jazira Plain occurred due to the stretching of the Arabian Plate. The stretching was enough to generate systems of intercontinental elongated graben and half-graben rift 


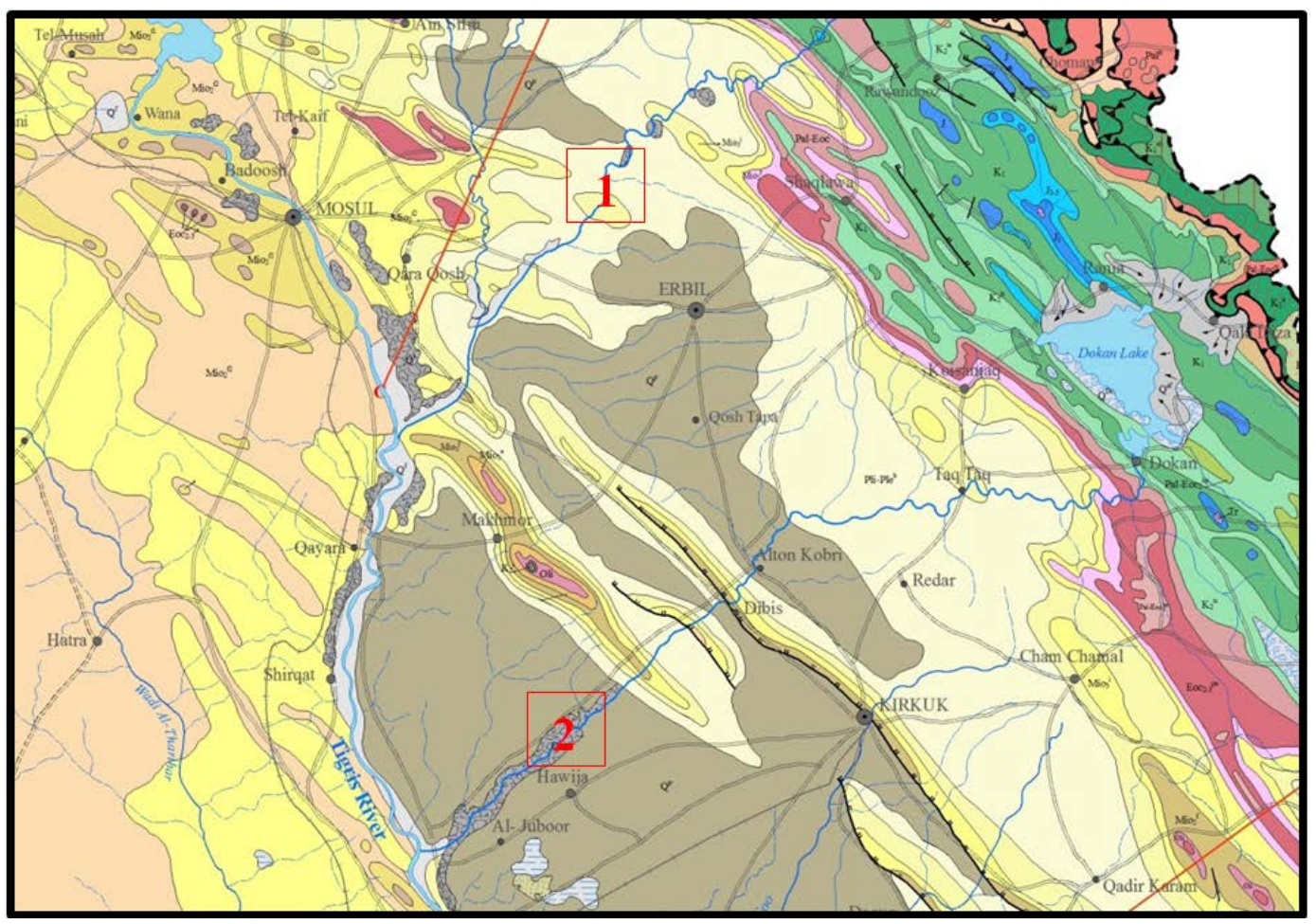

Figure 2. Geological map (scale 1:2000,000) [18]. 1 = Greater Zab River, 2 = Lesser Zab River. For legend, refer to Figure 3.

basins in northern Arabia [13] [39]. The Late Cretaceous formation of the deep basement involved in the southern part of Al-Jazira Plain, resulted in the separation of Khlesia High from the rest of Hail-Rutbah Arch, which extends from the Saudi Arabia to Iraq. The later Paleogene-Neogene development is completely independent on that of its former southern Hail-Rutbah extension.

During the Paleocene, the obduction was completed and the final closure of the Neo-Tethys occurred and compression started [12], which is represented by Kolosh Formation. Aaliji Formation represents the open marine origin forming post-rift sediments.

At the beginning of the Eocene, the gradual rise of the sea level led to the deposition of the open marine carbonates, as the early postrift units over the eroded Late Cretaceous synrift sequence. The deposition was continued until Oligocene, when sharp sea level drop occurred, but still the region was below the sea level, therefore thin Oligocene sequence was deposited.

At the end of the Eocene, the main intraplate basin became narrower due to the tilting of west Arabia. The closed Neo-Tethys was narrow seaway in which marine carbonates were deposited. The Oligocene basin was relatively narrow; because the Neo-Tethys was a narrow seaway forming reef back reef and fore reef basins. Thick fringing reefs developed along the western and eastern shorelines of the basin [12].

During the Oligocene the deposition was continuous, when sharp sea level drop occurred, but still the region was below the sea level, therefore, the Oligocene sequence is very restricted in Iraq.

During the Early Miocene, Savian movements caused development of broad and shallow basins in which carbonates were deposited, whereas in the coastal parts clastics were deposited. Both deposits pass to each other laterally indicating irregular shore line of the basin.

During the Middle Miocene the marine transgression extended south and southwestwards forming shallow basins, with carbonate deposits, whereas in closed lagoons evaporates were deposited.

During the Late Miocene, the marine phase was changed to continental and only clastics were deposited, due to the collision of the Eurasian and Arabian Plates. During the Late Miocene-Pliocene, major thrusting occurred due to the collision of the Arabian Plate with the Sanandaj-Sirjan Zone. Consequently, the High Folded and the Imbricate Zones were uplifted. A major foredeep formed in the Low Folded Zone, which was filled by molasse sediments that increased in size continuously, the erosion products were laid down in the foredeep as continental 
sediments that represent the end of the last marine phase and beginning of the continental phase. At the end of the Pliocene, the Low Folded Zone was uplifted and deformed giving rise of long anticlines, which are separated by wide synclines. The Pliocene molasses were deposited in a rapidly sinking basin in the foredeep, they have large extensions in the northeastern, middle, and southern parts of Iraq, while in the western and northwestern parts it was not deposited, mainly due to the presence of Rutbah and Mosul Highs.

During the Pliocene-Pleistocene the landforms started to shape their selves forming almost the nowadays landscapes with slight modifications, mainly due to erosion and/or deposition.

\section{Main Linear Features}

Different linear features with NE-SW occur in Iraq, represented by rivers, streams, valleys, playas... etc. Hereinafter are the most prominent features, their geological, geomorphological, tectonic and structural aspects are described for each case, with discussing their origin.

\subsection{Greater Zab River}

The Greater Zab River is one of the main tributaries of the Tigris River. The catchment of this tributary lies in Turkey, Iran and Iraq. Its total length is $437 \mathrm{~km}$. It crosses the Turkish-Iraqi border in the north and it follows many anticlines and meanders around their plunges until it flows out of the mountainous area. There it flows in almost straight line with NE-SW trend (Figure 2 \& Figure 3).

The Greater Zab River, in its NE-SW trend dissects many anticlines forming water gaps [40] (Ramsey et al., 2008), mainly in clastic rocks of Mukdadiya (Late Miocene-Pliocene) and Bai Hassan (Pliocene-Pleistocene) formations, until it merges with the Tigris River. All the dissected anticlines have NW-SE trend (Figure 4). The

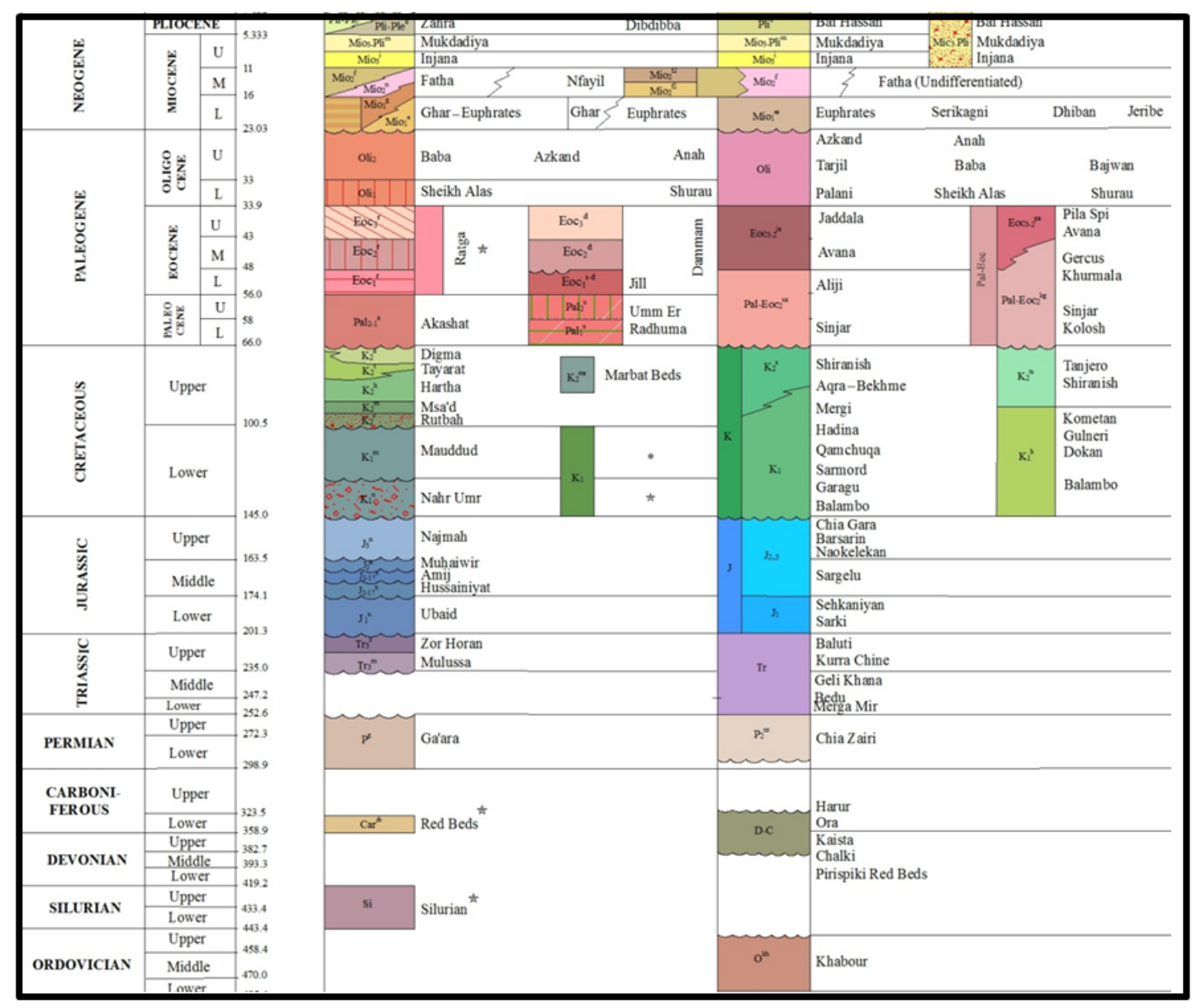

Figure 3. Legend for Figure 2, Figure 7, Figure 9 and Figure 13. 


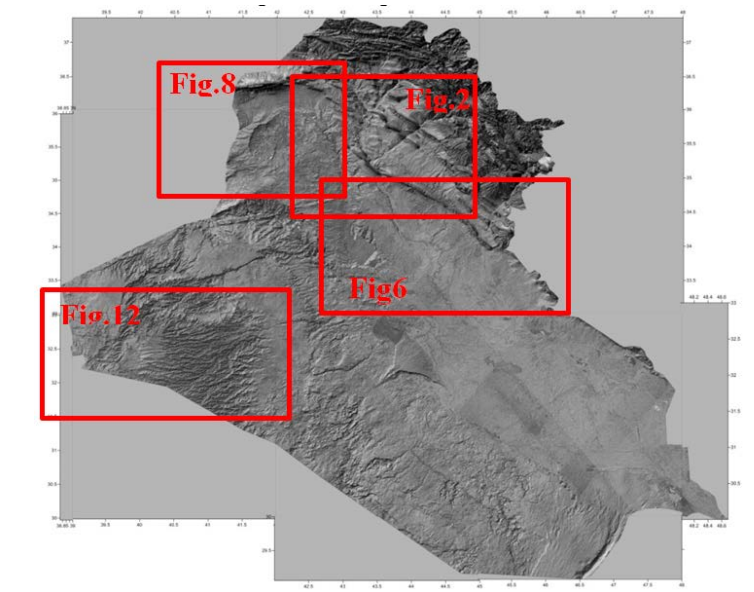

Figure 4. Digital Elevation Model (DEM) image showing the studied areas.

river almost coincides with the supposed deep seated fault called as "Hadr-Bekhme Fault” (Figure 5) [10] [12]. No surface rupture or dislocated features occur in the involved area [32], especially in its part east of the Tigris River. However, Fouad [5] denied the occurrence of the mentioned fault, but mentioned Greater Zab Fault, to coincide with the Greater Zab River [41].

When reviewing the Bouguer gravity and Total magnetic field maps [12] (Figure 6), no indication can be seen, which confirms the supposed deep seated fault [10] [12].

\subsection{Lesser Zab River}

The Lesser Zab River is another main tributary of the Tigris River. The total catchment area of this tributary is $22,250 \mathrm{~km}^{2}$ of which $5975 \mathrm{~km}^{2}$ lie in Iran and the remainder in Iraq. The total length of the river is $456 \mathrm{~km}$. It inters from Iran in the northeast of Iraq, follows many anticlines and meanders around their plunges until it flows out of the mountainous area. There it starts meandering; locally following plunges of anticlines, and flows in almost straight line with NE-SW trend until it merges with the Tigris River (Figure 2 \& Figure 3).

The Lesser Zab River, in its NE-SW trend dissects many anticlines forming water gaps [40], mainly in clastic rocks of the Injana (Late Miocene), Mukdadiya (Late Miocene-Pliocene) and Bai Hassan (Pliocene-Pleistocene) formations, besides large parts, which are covered by polygenetic sediments of Quaternary age. All the dissected anticlines have NW-SE trend (Figure 2 \& Figure 3). The river almost coincides with the supposed deep seated fault referred to “Anah-Qal'at Diza Fault” (Figure 5) [10] [12], especially in its east part of the Tigris River. No surface rupture or dislocated features occur in the involved area [32]. However, Fouad [5] denied the occurrence of the mentioned fault, in pointed another fault "Lesser Zab Fault" to coincide with the Lesser Zab River [41].

When reviewing the Bouguer gravity and total magnetic field maps [12] (Figure 6), no indication can be seen, which confirms the supposed deep seated fault by [10] [12].

\subsection{Three Tributaries of the Adhaim River}

The Adhaim River is another main tributary of the Tigris River; its drainage basin totally lies in the northeastern part of Iraq. The three tributaries of the Adhaim River are: Khas'sa Soo (A in Figure 7), Tawooq Soo (B in Figure 7) and Tuz Chai (C in Figure 7) (Soo and Chai are local names for stream) having almost NE-SW trend in their courses; although locally they deflect from the main trend (Figure 7).

The three tributaries dissect many anticlines forming water gaps and air gaps [40]. According to Sissakian and Abdul Jab’bar [15], the three tributaries have formed tens of water and air gaps; indicating active tectonic areas [40] [42]. The tributaries flow mainly in clastic rocks of the Injana (Late Miocene), Mukdadiya (Late MiocenePliocene) and Bai Hassan (Pliocene-Pleistocene) formations, besides large parts, which are covered by polygenetic sediments of Quaternary age. However, Tawooq Soo in the uppermost part of its course crosses thick carbonate rocks of the Pila Spi Formation (Eocene) and Oligocene and Early Miocene rocks too. All the dissected anticlines have NW-SE trend (Figure 7). The Tawooq Soo almost coincides with the supposed deep seated fault 


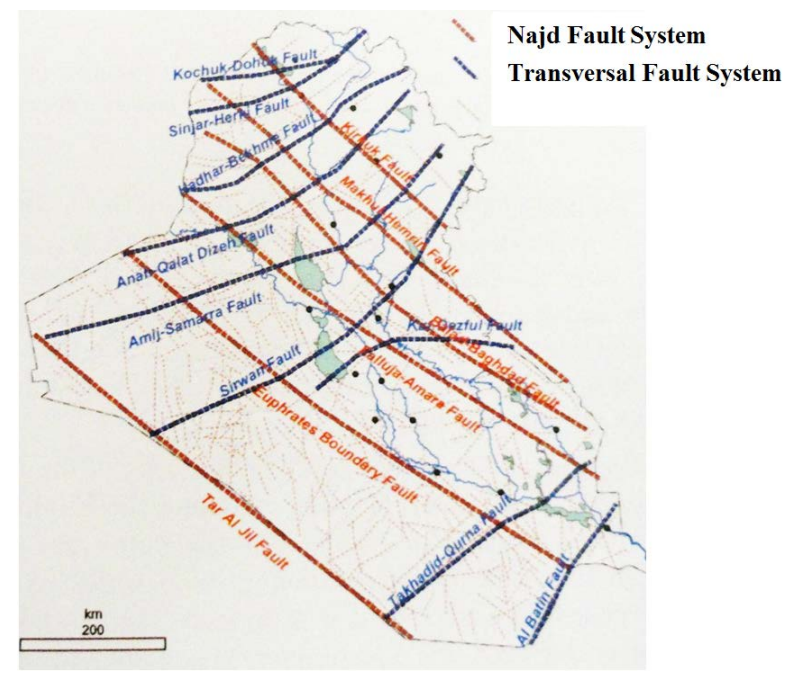

Figure 5. Transversal fault system [12].

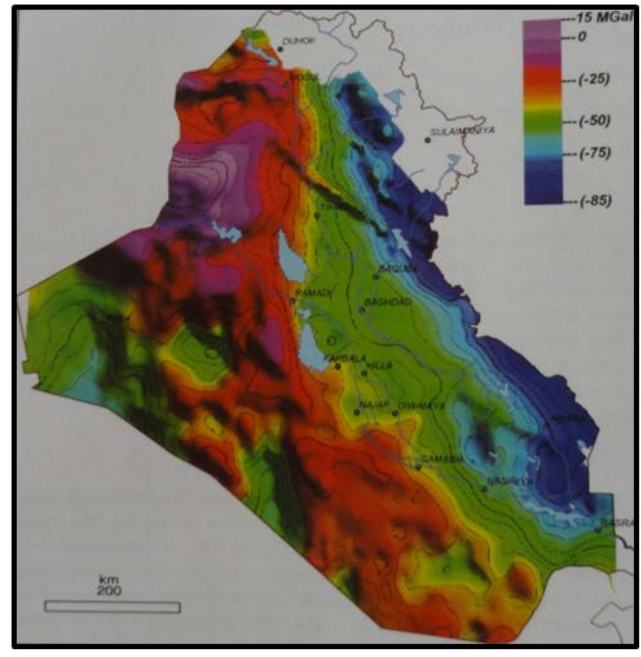

(a)

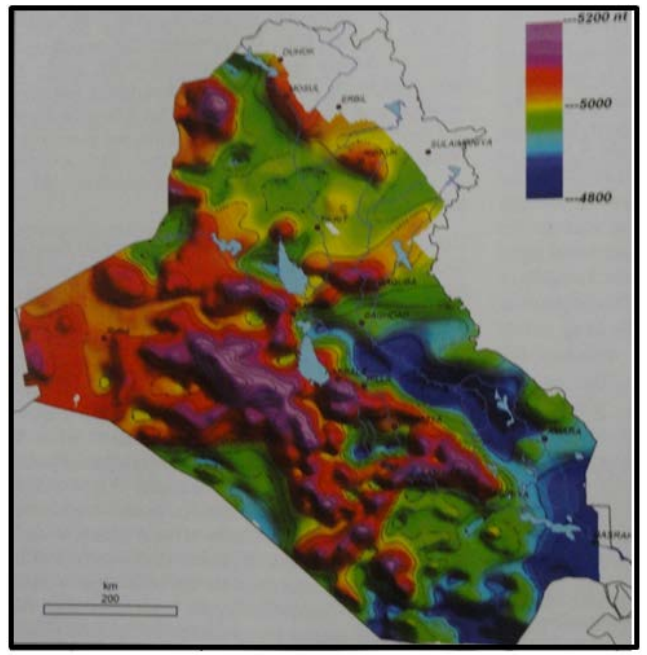

(b)

Figure 6. (a) Bouguer gravity map and (b) Total Magnetic Field map [12].

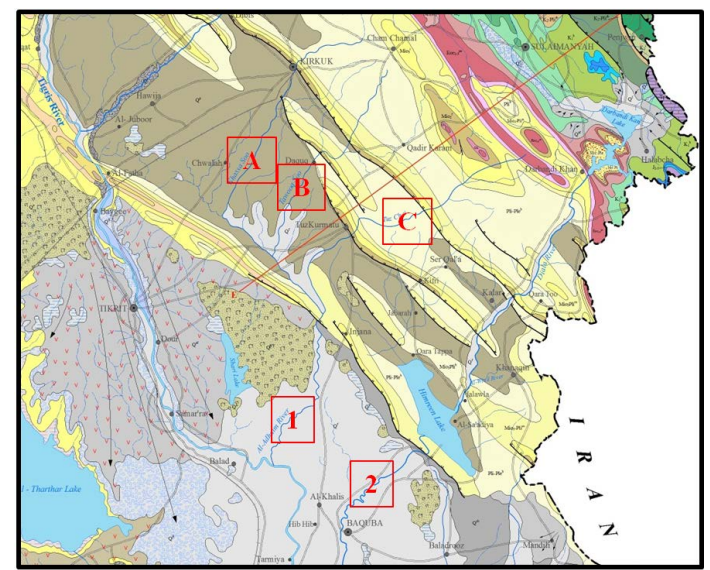

Figure 7. Geological map of the Adaim River (1), its three tributaries (A, B and C) and Diyala River (2) (scale 1:2,000,000) [32]. For legend, refer to Figure 3. 
called as “Amij-Samarra Fault” (Figure 5) [10] [12], especially in its parts east of the Tigris River. No surface rupture or dislocated features occur in this area [32]; however, Fouad [5] denied the occurrence of the mentioned fault.

When reviewing the Bouguer gravity and total magnetic field maps [12] (Figure 6), no indication can be seen, which confirms the presence of the supposed deep seated fault by [10] [12].

\subsection{Adhaim River}

The Adhaim River is another main tributary of the Tigris River. The tributary drains an area of 13,000 $\mathrm{km}^{2}$ lying within Iraq. Its length is $330 \mathrm{~km}$. The river has NE-SW trend in the lower part of its course until it merges with the Tigris River (Figure 3 \& Figure 7).

The Adhaim River, in its NE-SW trend flows in area covered totally by polygenetic sediments of Quaternary age. No deep seated fault occurs to coincide with the course of the river (Figure 5) as those mentioned by [10] [12]. No surface rupture or dislocated features occur in this area [5] [32].

\subsection{Diyala (Sirwan) River}

The Diyala River is the last main tributary of the Tigris River. Diyala's drainage basin is 31,896 $\mathrm{km}^{2}$ of which $20 \%$ lies in Iran and the rest in Iraq. The length of the river is $574 \mathrm{~km}$. It inters from Iran from the northeast of Iraq. It follows many anticlines and meanders around their plunges until it flows out of the Derbendi Khan Lake. There it starts meandering; locally following plunges of anticlines, and flows in almost straight line with NE-SW trend until Ba'qooba city (Figure 7).

The Diyala River, in its NE-SW trend dissects many anticlines forming water gaps [40], mainly in clastic rocks of the Injana (Late Miocene), Mukdadiya (Late Miocene-Pliocene) and Bai Hassan (Pliocene-Pleistocene) formations, besides large parts, which are covered by polygenetic sediments of Quaternary age. However, in the uppermost part of its course, it crosses carbonates of the PilaSpi Formation and Oligocene and Early Miocene rocks too. All the dissected anticlines have NW-SE trend (Figure 7). The river almost coincides with the supposed deep seated fault called as "Sirwan Fault" (Figure 5) [10] [12], especially in its northeast of the Tigris River. Clear surface rupture and/or dislocated features occur in this area (Figure 8) [5] [32] [41].

When reviewing the total magnetic field map [12] (Figure 6), clear indication can be seen, which confirms the supposed deep seated fault by [10] [12]; however, this is not clear in the Bouguer gravity map.

\subsection{Elongated Playas}

The Ashqar marsh (playa) (Figure 9) is one of the prominent salt marshes in the Jazira Plain. It has elongated shape bounded between two NE-SW lineaments that extend for about $100 \mathrm{Km}$ and height of (8 - 15) m [14].

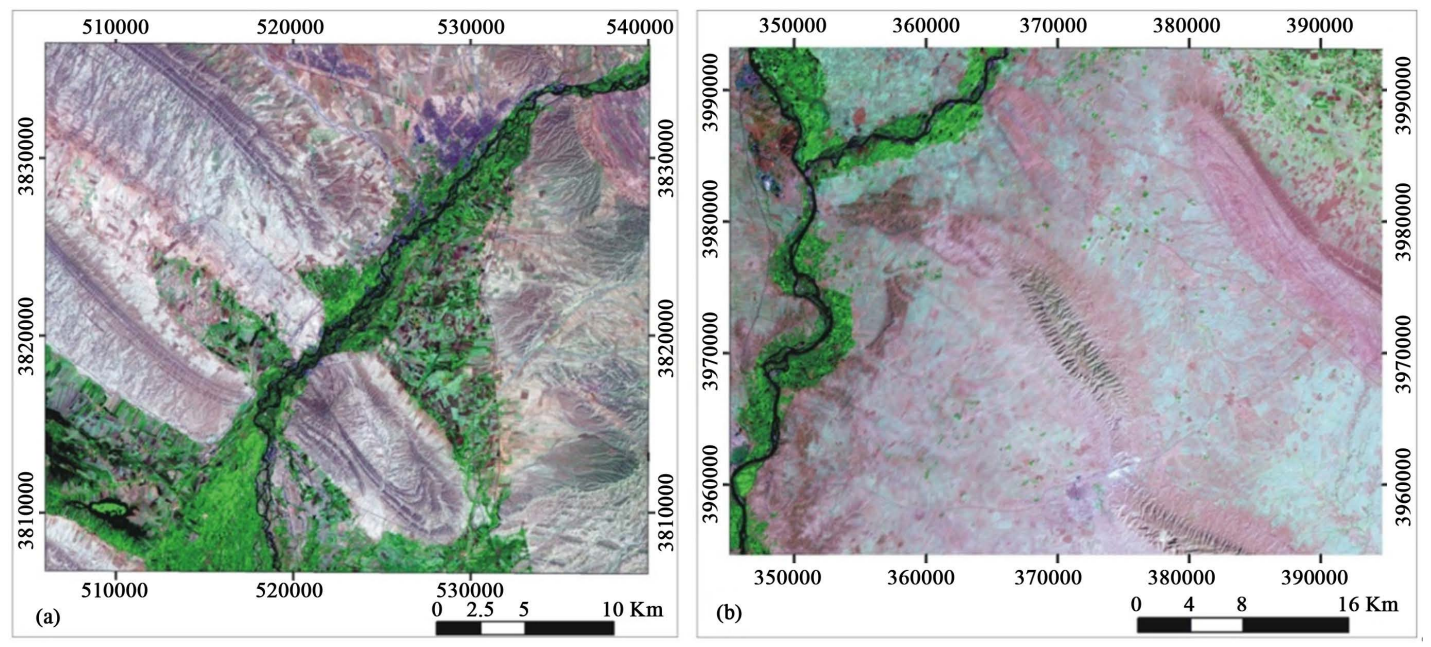

Figure 8. Satellite images showing: (a) Sharp change in fold geometry across Diyala (Sirwan) River Transverse Fault; (b) Fold axis deflection close to Greater Zab River Transverse Fault [41]. 


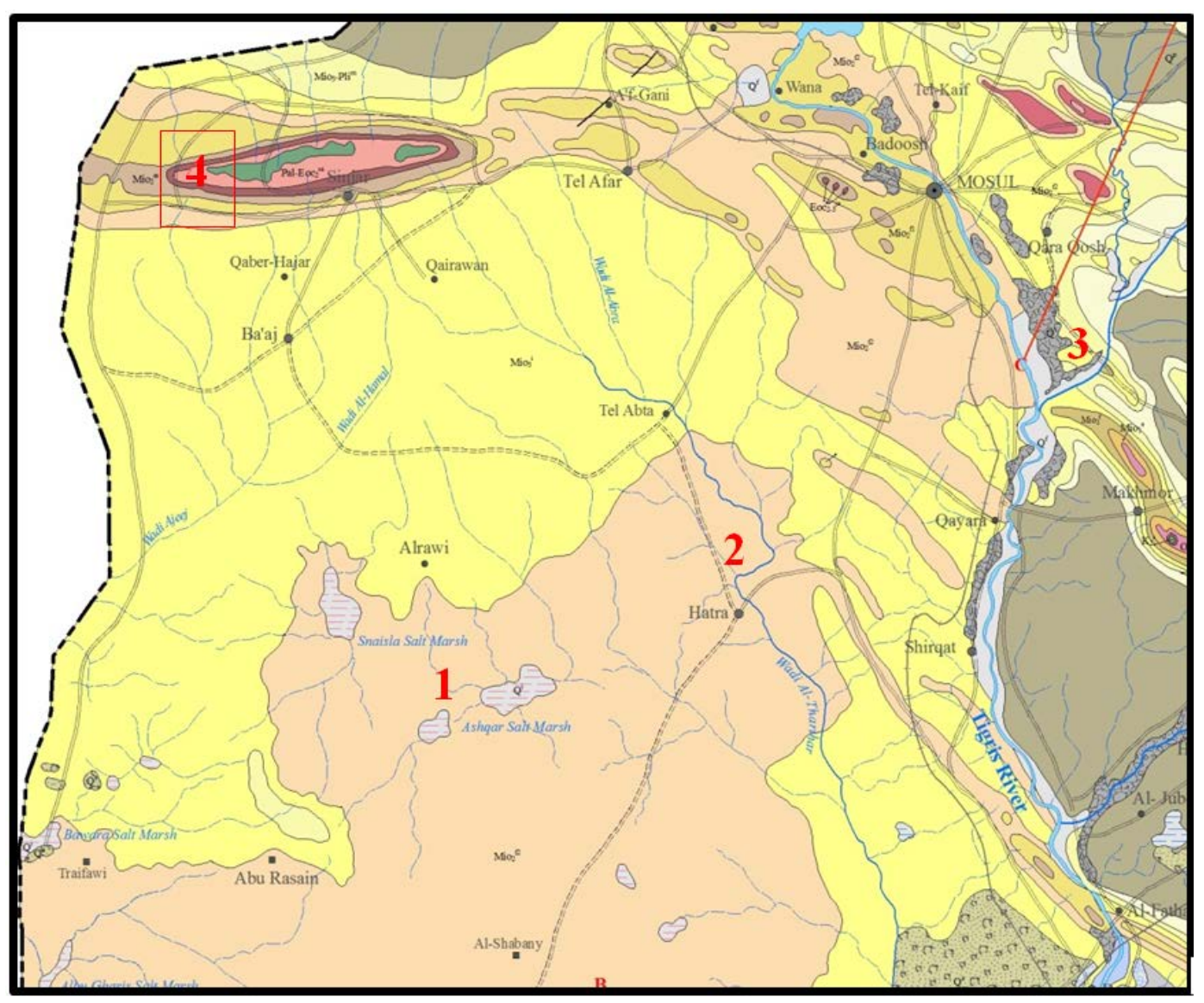

Figure 9. Geological map of the Jazira plain [32]. Note: 1 = Ashqar marsh (playa), 2 = offset of Tharthar valley, 3 = Greater Zab River, and 4 = Sinjar anticline (scale 1:20,000,000), for the legend, refer to Figure 3.

Northeast wards, the same lineament have clearly dislocated the course of Tharthar valley (Figure 9) for about $10 \mathrm{Km}$ (Figure 10). Moreover, the contact between the Injana Formation and the Upper Member of the Fatha Formation is also controlled by NE-SW lines (north and south of Point 2, Figure 9).

The Ashqar salt marsh is developed within the Fatha Formation (Middle Miocene), the formation consists of cyclic nature, and each cycle consists of green marl, limestone and gypsum, overlain by clastic rocks of the Injana Formation (Late Miocene) (Figure 9). The two lineaments (Figure 10), which bound the salt marsh run parallel to the supposed deep seated fault referred to as "Hadr-Bekhme Fault" (Figure 5) [10] [12]. Clear surface rupture and/or dislocated features occur in this area (Figure 10) [14] [32]. Moreover, Fouad and Nasir [13] (Figure 10) and Fouad [5] confirmed the occurrence of subsurface grabens with almost NE-SW trends in the Jazira Plain.

When reviewing the Bouguer gravity and total magnetic field maps [12] (Figure 6), clear indications can be seen, which confirm the supposed deep seated fault (Hadr-Bekhme) mentioned by [10] [12].

\subsection{Sinjar Anticline}

Sinjar Mountain is a conspicuous geomorphological form outstanding in between the surrounding plains. The height of the mountain attains $1200 \mathrm{~m}$ above sea level (a.s.l.). It forms a double plunging anticline called Sinjar anticline with ENE-WSW trend in which the Late Cretaceous Shiranish formation is exposed as the oldest exposed rocks, forming synrift sediments; followed upwards by postrift sediments of Aaliji Formation (Paleocene) (Figure 9), indicating that the anticline was originally a graben, which was inverted to anticline.

Sinjar anticline with its ENE-WSW trend follows the same trend of the subsurface grabens and Khlesia High in the Jazira Plain. Eastwards, few small double plunging anticlines have the same trend; until Tel Afar town (Figure 3 \& Figure 9). There the trend of the structures changes to NW-SE. The anticline almost coincides 


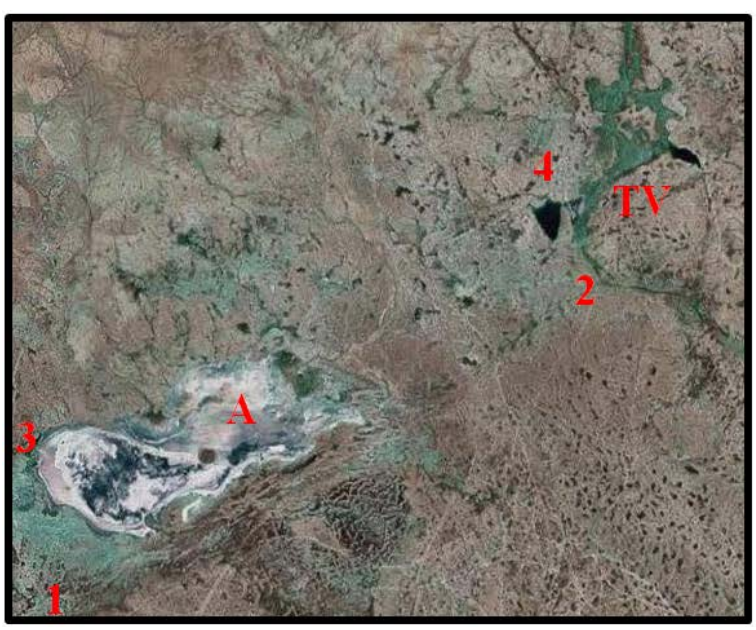

(a)

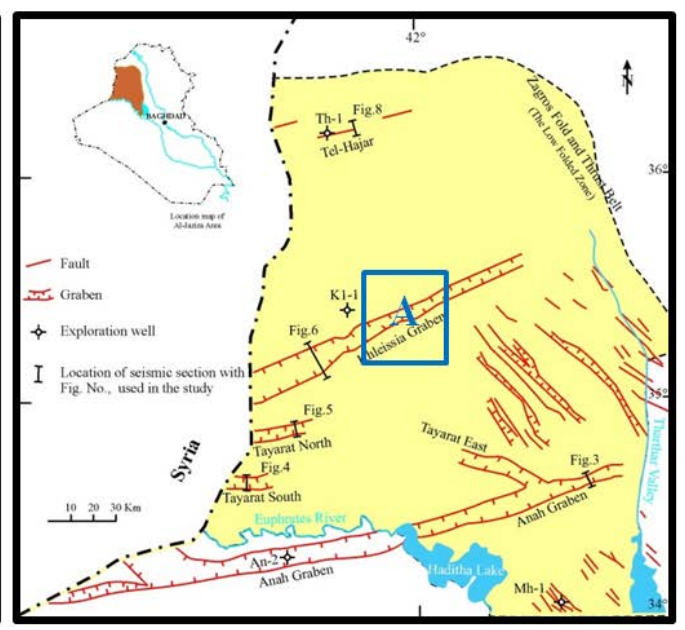

(b)

Figure 10. (a) Google Earth image of Ashqar: (a) Salt marsh (playa), note the dislocated Tharthar valley (TV) and the two lineaments (1 - 2 and 3 - 4); (b) Tectonic map of Al-Jazira Plain [13], note the NE-SW extension of subsurface grabens. $\mathrm{A}=$ the approximate location of Ashqar salt marsh.

with the supposed deep seated fault called as "Sinjar-Herki Fault" (Figure 5) [10] [12], especially in west of the Tigris River. No any surface rupture or dislocated features occur in the involved area [32]. However, Fouad [5] denied the occurrence of the mentioned fault, but, mentioned another fault; called "Bai'Khair-Sasan Fault" (Figure 11) [41].

The Bai'Khair-Sasan Fault has very clear surface ruptures and dislocated features [43] [44] (Figure 11). The fault was adopted by [5] [32] [41] [45] [46].

When reviewing the Bouguer gravity and Total magnetic field maps [12] (Figure 6), no indication can be seen, which confirms the supposed deep seated fault (Sinjar-Herki) by [12].

\subsection{Anah Anticline}

Anah Mountain is a conspicuous geomorphological form outstanding in between the surrounding plains. The height of the mountain attains $250 \mathrm{~m}$ (a.s.l.). It forms a double plunging anticline called Anah anticline with ENE-WSW trend in which the Oligocene rocks are exposed as the oldest exposed rocks (Figure 12). The anticline was originally a subsurface graben, but was inverted to anticline [13] [47].

Anah anticline with its ENE-WSW trend follows the same trend of the subsurface grabens and Khlesia High in the Jazira Plain. Eastwards, it crosses the Euphrates River and plunges in the Jazira Plain, but the plunge is not so clear due to very gentle dipping of rocks of the Fatha Formation (Figure 12). The anticline almost coincides with the supposed deep seated fault called as "Anah-Qalat Dizah Fault” (Figure 5) [10] [12], especially in its part south of the Euphrates River. No any surface rupture or dislocated features occur in the involved area [32]. However, Fouad [5] denied the occurrence of the mentioned fault, but, mentioned the presence of subsurface inverted graben in the involved area (Figure 10) [13] [47]. Moreover, a small anticline is present in the extension of Anah anticline towards NE, it is called "Al-Qanatir anticline” [48] (Figure 13).

When reviewing the Bouguer gravity and Total magnetic maps [12] (Figure 6), a faint indication can be seen only in the former map, which confirms the supposed deep seated fault (Aanh-Qalat Diza) by [10] [12].

\subsection{Hauran Valley}

Hauran valley is one of the largest valleys in the Iraqi Western and Southern Deserts with a total length of about $120 \mathrm{Km}$. Its main trend is NE-SW, locally; however, some deflections from the main trend occur (Figure 12). In its middle part, where the Dammam Formation (Eocene) is exposed in the base, the valley has canyon shape, with height of the banks attaining $120 \mathrm{~m}$, but generally the depth of the valley ranges from (5 - 35) m. Rocks of Triassic-Miocene are exposed along its course; the strike of the beds is almost parallel to the valley course, with some exceptions (Figure 12). 


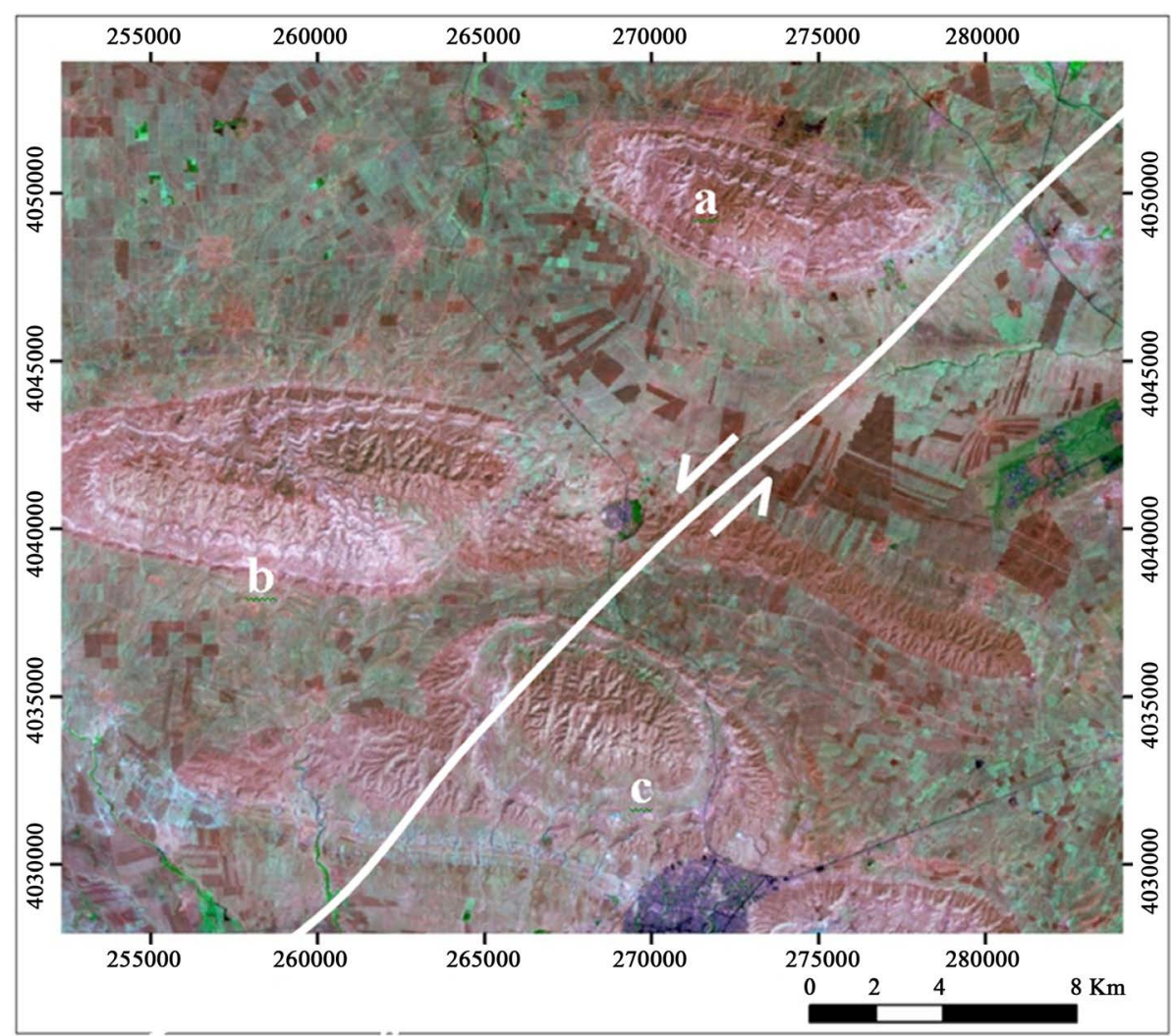

Figure 11. Satellite image showing Baikhair-Sasan left-lateral strike-slip fault. Note the displaced axes and limbs and sharp changes in fold geometry across the fault: (a) Qusair; (b) Shkaft; and (c) Sasan anticlines.

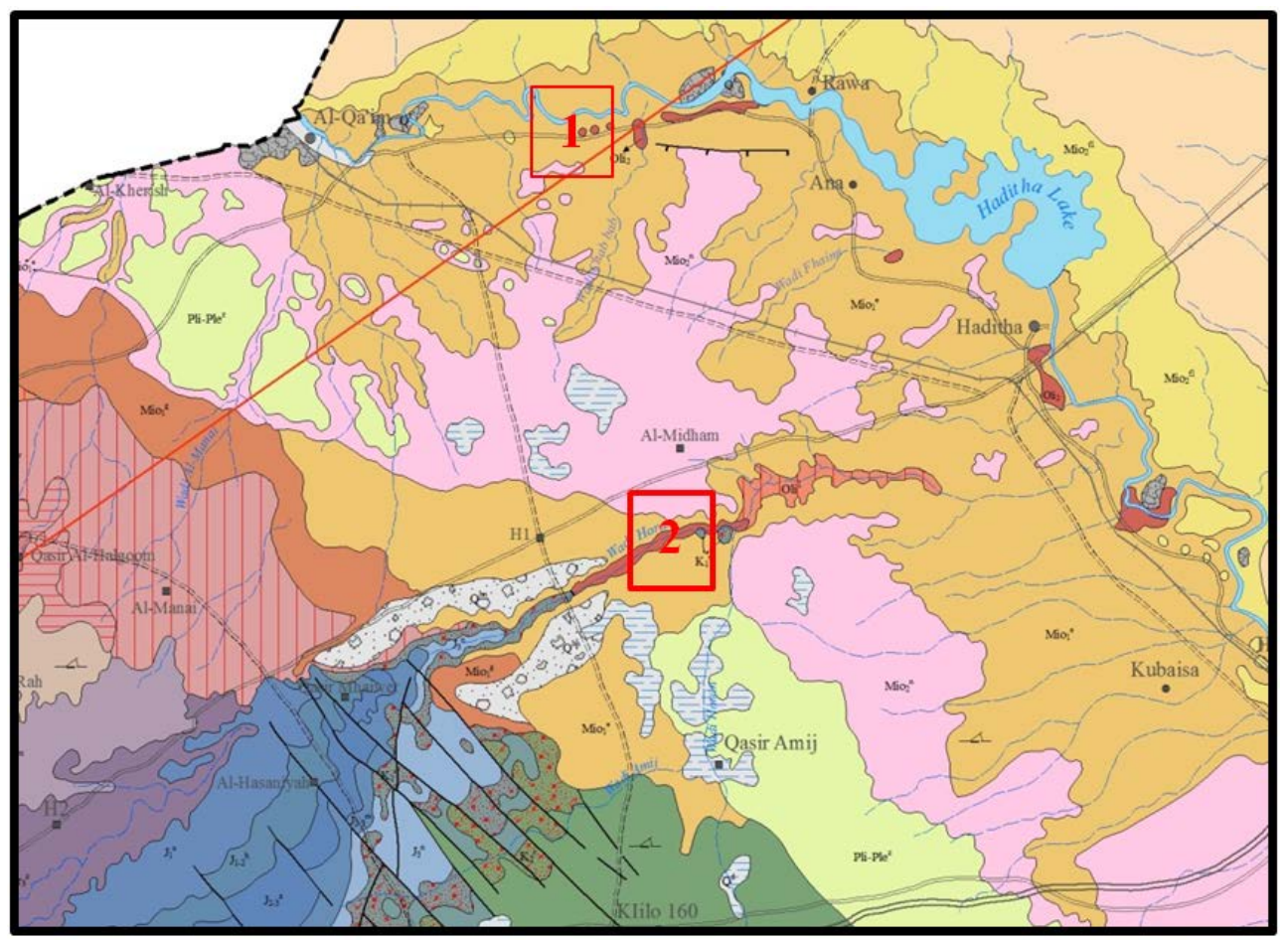

Figure 12. Geological map of the middle part of the Iraqi Western Desert [32] (scale 1:20,000,000). For the legend, refer to Figure 3, 1 = Anah anticline, and 2 = Hauran valley. 
Jassim and Goff [12] considered the presence of an anticline with NE-SW trend, the axis being along Hauran valley. However, the detailed geological mapping of the area does not confirm this assumption, which is adopted by Sissakian and Fouad [32] and Fouad [5].

The supposed deep seated fault called "Amij-Samara Fault" (Figure 5) by [10] [12] coincides partly with the course of Hauran valley, especially in its part west of the Euphrates River. No surface rupture or dislocated features occur in the involved area, apart from NW-SE trending fault [32]. Fouad [5]; however, denied the occurrence of the mentioned fault and the anticline.

When reviewing the Bouguer gravity and Total magnetic maps [12] (Figure 6), a faint indication can be seen, which confirms the supposed deep seated fault (Amij-Samara) by [10] [12].

\section{Discussion}

Linear features of NE-SW trend represented by rivers, streams, playas, and anticlines are very common in different parts of Iraq. They are formed perpendicular to the main trend of the existing anticlines, which is NW-SE, in majority parts of Iraq. These linear features are formed due to compressional forces created during the last phase of the Alpine Orogeny during Pliocene-Pleistocene, which is still in progress, and due to collision of Arabian Platform with Sanandaj-Serjan Zone during Late Miocene and the accompanied major thrust that had occurred contemporaneously. The straight courses of some rivers in NE-SW trend with existence of tens of water and wind gaps are very clear indications for continuous growth of the anticlines, which are dissected by the rivers, indicating that the incision of the rivers was faster than the growth of the anticlines.

\subsection{Rivers, Streams and Valleys}

In the Low Folded Zone area, where the Greater Zab, Lesser Zab, Adhaim; with its three tributaries, and Diyala rivers all have almost NE-SW trend. Their courses dissect mainly clastic weak rocks of Neogene age, with some exceptions of carbonate rocks. These rivers are considered by Buday and Jassim [10] and Jassim and Goff [12] to coincide with many deep seated faults (Figure 5). Apart from Diyala River that coincides with Sirwan Fault and shows clear dislocation of the beds along both banks (Figure 8), none of the remaining deep seated faults have clear surface indications, even in the Bouguer gravity and Total magnetic maps (Figure 6). The same is true with Hauran valley that coincides with the deep seated Amij-Samara Fault (Figure 5 and Figure 12 and Figure 13).

The existence of these linear features in weak clastic rocks and Quaternary sediments, and their disappearance in hard carbonate rocks along the same extension of the features can be attributed to the presence of weakness zones along the features, which are utilized as rivers and streams. However, if the weakness zones were deep seated faults; as considered by [10] [12], then why their extensions are not present in hard carbonate rocks? Therefore, it is believed that these weakness zones are most probably not faults, but compressional weakness zones along shear planes, apart from those which show clear surface dislocations, like Diyala River and Sirwan Fault. Moreover, the Bouguer gravity and Total magnetic maps did not show clear evidences for existence of the supposed deep seated faults (Figure 5).

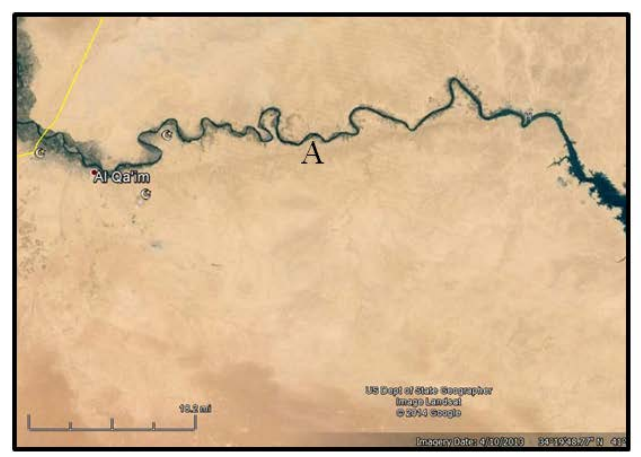

(a)

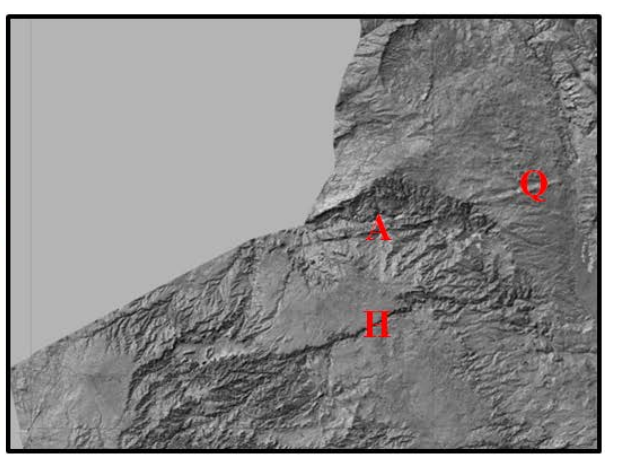

(b)

Figure 13. (a) Google Earth image of Anah anticline (A); (b) DEM image, A = Anah anticline, Q = Al-Qanatir anticline, $\mathrm{H}=$ Hauran valley. 


\subsection{Elongated Playas}

Ashqar playa (salt marsh) is an elongated depression bounded between two lineaments with NE-SW trend (Figure 9 and Figure 10), with height of cliffs on both sides that range from (8 - 15) m [14]. The two lineaments coincide with the subsurface grabens (Figure 10), which show clear surface dislocation for the course of Tharthar valley. Moreover, the Neotectonic map also shows clear evidences for the existence of the grabens in the Jazira area; particularly along Ashqar playa (Figure 14), beside the evidences in Bouguer gravity and Total magnetic maps (Figure 5).

\subsection{Anticlines}

Both Sinjar and Anah anticlines have ENE-WSW trend, which is also considered as transversal features to the main compressional forces that have initiated anticlines with the main NW-SE trend. Both anticlines are supposed to coincide with deep seated faults (Sinjar-Herki and Anah-Qalat Diza, respectively) [10] [12]. However, both faults show no surface indication for faulting, in contrary; the inverted subsurface grabens (Figure 10) are more clearly evidenced on surface, like the Sasan-Bai'Khair Fault and the dislocation of Tharthar valley (Figure 10 and Figure 11).

\section{Conclusions}

From this study the following conclusions can be achieved:

- The linear features of NE-SW and ENE-WSW trends are present in different parts of Iraq, represented by rivers, streams, valleys, playas and anticlines.

- The NE-SW trend features coincide with weakness zones formed due to compressional forces that have initiated the anticlines with their main trend being NW-SE. The weakness zones are formed by compressional forces along shear zones. They also have manifested their effect on surface only in weak clastic rocks and Quaternary sediments; in contrary they have never influenced the hard carbonate rocks, along the same extensions.

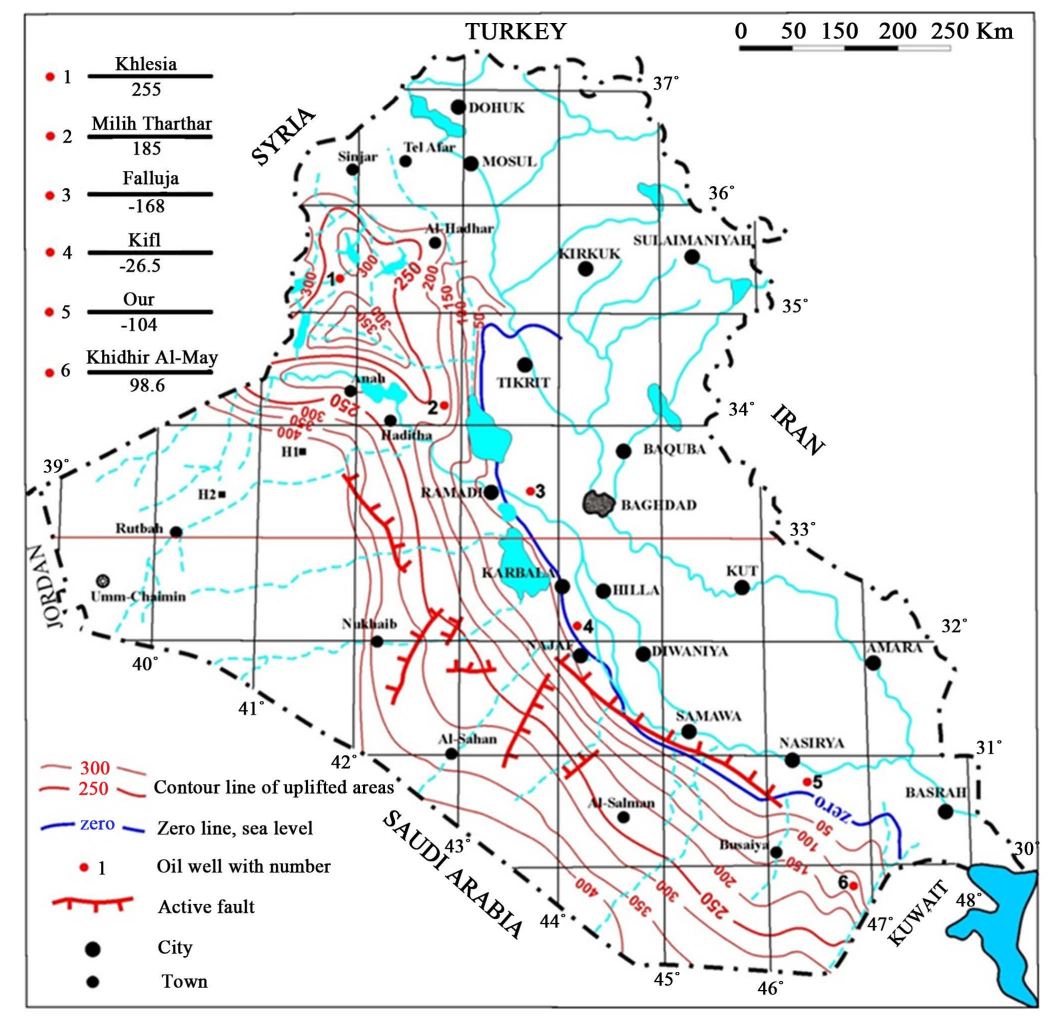

Figure 14. Neotectonic map of the western part of Iraq (after Sissakian and Deikran, 2009). 
- Some of the deep seated supposed faults do occur in small parts of their supposed extensions; others are doubtful, since no surface evidence is present to prove them.

\section{References}

[1] Dunnington, H.V. (1958) Generation, Migration, Accumulation and Dissipation of Oil in Northern Iraq. Weeks, L.G., Ed., Habitite of Oil, Symposium, American Association of Petroleum Geologists, 1194-1251.

[2] Mitchell, R.C. (1959) The Tectonic Foundation and Character of S.W. Asia. Egyptian Journal of Geology, 3, 1-70.

[3] Ihan, E. (1967) Toros-ZAGROS Folding and Its Relation to Middle East Oil Fields. The American Association of Petroleum Geologists Bulletin, 51, 651-667.

[4] Tikrity, S.S. and Al-Ani, A.A. (1972) Precamberian Basement of Iraq. Eighth Arab Petroleum Congress, Beirut, 22-26 September 1972.

[5] Fouad, S.F. (2012) Tectonic Map of Iraq, Scale 1:1000000. 3rd Edition, GEOSURV, Baghdad.

[6] Al-Ansari, N. (1972) Geology of the Southern Part of Jabal Makhul (Quadrangles NI-38-0285 and NI-38-0196). M.Sc. Thesis, Baghdad University, Baghdad.

[7] Barazanji, A. and Al-Ansari, N. (1984) Geological and Geophysical Analysis of Fatha Area. Journal of Water Resources, 3, 141-181.

[8] Gayarah, A. (1976) Geology of Parts of Khanuqa and Makhul Anticlines. M.Sc. Thesis, Baghdad University, Baghdad.

[9] Buday, T. (1980) The Regional Geology of Iraq, Part I, Stratigraphy and Paleogeography. Kassab, I.I. and Jassim, S.Z., Eds., GEOSURV, Baghdad, 445.

[10] Buday, T. and Jassim, S.Z. (1984) Tectonic Map of Iraq, Scale 1:1,000,000. GEOSURV, Baghdad.

[11] Al-Kadhimi, J.A.M., Sissakian, V.K., Satter, A.F. and Diekran, D.B. (1996) Tectonic Map of Iraq, Scale 1:1,000,000. 2nd Edition, GEOSURV, Baghdad.

[12] Jassim, S.Z. and Goff, J.C. (2006) Geology of Iraq. Dolin, Prague and Moravian Museum, Brno, 341.

[13] Fouad, S.F.A. and Nasir, W.A.A. (2009) Tectonic and Structural Evolution of Al-Jazira Area. Geology of Al-Jazira Area, Iraqi Bulletin of Geology and Mining, Special Issue, 33-48.

[14] Sissakian, V.K. and Abdul-Jabbar, M.F. (2009) Remote Sensing Techniques and GIS Applications in Detecting Geohazards in the Jazira Area, West Iraq. Iraqi Bulletin of Geology and Mining, 5, 47-62.

[15] Sissakian, V.K. and Abdul-Jabbar, M.F. (2010) Morphometry and Genesis of the Main Transversal Gorges in North and Northeast Iraq. Iraqi Bulletin of Geology and Mining, 6, 95-120.

[16] Sissakian, V.K. (2011) Alluvial Fans of Sinjar Mountain, NW Iraq. Iraqi Bulletin of Geology and Mining, 7, 9-26.

[17] Sissakian, V.K. (2011) Origin of the Tharthar Depression, Central Part of Iraq. Iraqi Bulletin of Geology and Mining, 7, 47-62.

[18] Fouad, S.F. and Sissakian, V.K. (2011) Tectonic and Structural Evolution. Geology of the Mesopotamia Plain, Iraqi Bulletin of Geology and Mining, Special Issue No. 4, 33-46.

[19] Holmes, A. (1965) Principles of Physical Geology. 2nd Edition, The Ronald Press, New York, 1288.

[20] Ivanhoe, L.F. (1967) Crustal Movements in the Arabian Region. Geotimes, 12, 12-13.

[21] McKanzie, D.P. (1970) Plate Tectonics of the Mediterranean Region. Nature, 226, 239-243. http://dx.doi.org/10.1038/226239a0

[22] McKanzie, D.P., Davies, D. and Molnar, P. (1970) Plate Tectonics of the Red Sea and East Africa. Nature, 226, 243248. http://dx.doi.org/10.1038/226243a0

[23] Lort, J.M. (1971) The Tectonics of Eastern Mediterranean: A Geological Review. Reviews of Geophysics, 9, 189-216. http://dx.doi.org/10.1029/RG009i002p00189

[24] Le Pichon, X. (1968) Sea-Floor Spreading and Continental Drift. Journal of Geophysical Research, 73, 3661-3697. http://dx.doi.org/10.1029/JB073i012p03661

[25] Swartz, D.H. and Arden, D.P. (1960) Geologic History of Red Sea Area. American Association of Petroleum Geologists Bulletin, 44, 1621-1937.

[26] Henson, F.R.S. (1950) Cretaceous and Tertiary Reef Formation and Associated Sediments in the Middle East. American Association of Petroleum Geologists Bulletin, 34, 215-238.

[27] Lees, G.M. (1952) Foreland Folding. Quarterly Journal of the Geological Society, 108, 1-32. http://dx.doi.org/10.1144/GSL.JGS.1952.108.01-04.02

[28] Buday, T. (1970) Explanatory Notes to the Structural Sketch Map of Iraq. National Iraqi Minerall Company, Report 
Number 61.

[29] Buday, T. and Vanacek, M. (1971) Outlines of Mineral Occurrences of Iraq and General Mineral Investigation Program for 1971-1990. National Iraqi Mineral Company, Report Number 67.

[30] Henson, F.R.S. (1951) Observations on the Geology and Petroleum of the Middle East. Proceedings of 3rd World Petroleum Congress, Section 1, The Hague, 28 May-6 June 1951, 118-140.

[31] Fouad, S.F.A. (2012) Structural Zonation of Western Zagros Fold-Thrust Belt of Iraq. In: The Evolution of the Zagros-Makran Fold Belt from Turkey to SE Iran, Institute of Earth Science “Jaume Almera”, Barcelona.

[32] Sissakian, V.K. and Fouad, S.F. (2012) Geological Map of Iraq, Scale 1:1,000,000. 4th Edition, GEOSURV, Baghdad.

[33] Sissakian, V.K. (2013) Geological Evolution of the Iraqi Mesopotamia Foredeep and Inner Platform, and Near Surrounding Areas of the Arabian Plate. Journal of Asian Earth Sciences.

[34] Alsharhan, A.S. and Nairn, A.E.M. (1977) Sedimentary Basins and Petroleum Geology of the Middle East. Elsevier, Amsterdam, 811.

[35] Brew, G. (2001) Tectonic Evolution of Syria Interpreted from Integrated Geological and Geophysical Analysis. Ph.D. Dissertation, Cornell University, Ithaca.

[36] Alavi, M. (2004) Regional Stratigraphy of the Zagros Fold-Thrust Belt of Iran and Its Proforeland Evolution. American Journal of Science, 304, 1-20. http://dx.doi.org/10.2475/ajs.304.1.1

[37] Berberian, M. (1995) Master "Blind” Thrust Faults Hidden under the Zagros Folds: Active Basement Tectonics and Surface Morphotectonics. Tectonophysics, 241, 193-195, 197, 199-224. http://dx.doi.org/10.1016/0040-1951(94)00185-C

[38] Iraq Petroleum Company (IPC) (1963) Oil Production Data. GEOSURV, Baghdad.

[39] Peel, F. and Wright, A. (1990) Basin Analysis and Prospectivity of NW Iraq, Vol. 3, Structural Geology of Northern Iraq. BP/Idemitsu Study of NW Iraq, Iraqi National Oil Company-INOC-Report, Oil Estate Company Library, Baghdad.

[40] Ramsey, L.A., Walker, R.T. and Jackson, J. (2008) Fold Evolution and Drainage Development in the Zagros Mountains of Fars Province, SE Iran. Basin Research, 20, 23-48. http://dx.doi.org/10.1111/j.1365-2117.2007.00342.x

[41] Fouad, S.F. (2012) Western Zagros Thrust-Fold Belt: Part 1, The Low Folded Zone. Geology of the Low Folded Zone, Iraqi Bulletin of Geology and Mining, Special Issue No. 5, 39-62.

[42] Keller, E.A. and Pinter, N. (2002) Active Tectonics, Earthquakes, Uplift and Landscape. 2nd Edition, Prentice Hall, Upper Saddle River, 362.

[43] Mohi Ad-Din, R.M., Sissakian, V.K., Yousif, N.S., Amin, R.M. and Rofa, S.H. (1977) Report on the Regional Geological Mapping of Mosul-Tel Afar Area. GEOSURV, Baghdad.

[44] Taufiq, J.M. and Domas, J. (1977) Report on the Regional Geological Mapping of Duhok-Ain Zala Area. GEOSURV, Baghdad.

[45] Sissakian, V.K., Hagopian, D.H. and Ma’ala, Kh.A. (1996) Geological Map of Mosul Qyadrangle, Scale 1:250,000. GEOSURV, Baghdad.

[46] Al-Mosawi, H.A.S. (2002) Bakhair-Ishkaft Fault and Its Influence on Folding Process in North West Iraq. Unpublished M.Sc. Thesis, Baghdad University, Baghdad. (in Arabic)

[47] Fouad, S.F. (2007) Tectonic and Structural Evolution of the Iraqi Western Desert. Geology of Iraqi Western Desert, Iraqi Bulletin of Geology and Mining, Special Issue No. 1, 29-50.

[48] Ibrahim, Sh.B. and Sissakian, V.K. (1976) Report on the Regional Geological Mapping of the Al-Jazira Area-RawaBaiji-Tikrit-Al-Baghdadi. GEOSURV, Baghdad. 
Scientific Research Publishing (SCIRP) is one of the largest Open Access journal publishers. It is currently publishing more than 200 open access, online, peer-reviewed journals covering a wide range of academic disciplines. SCIRP serves the worldwide academic communities and contributes to the progress and application of science with its publication.

Other selected journals from SCIRP are listed as below. Submit your manuscript to us via either submit@scirp.org or Online Submission Portal.
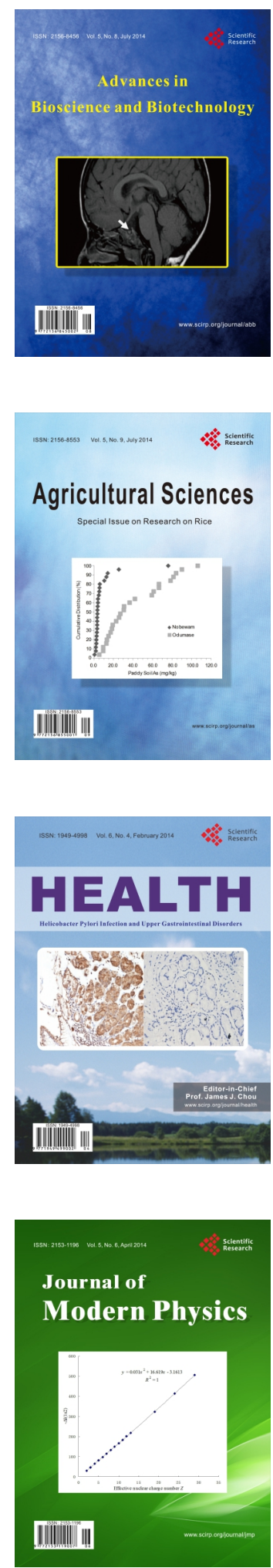
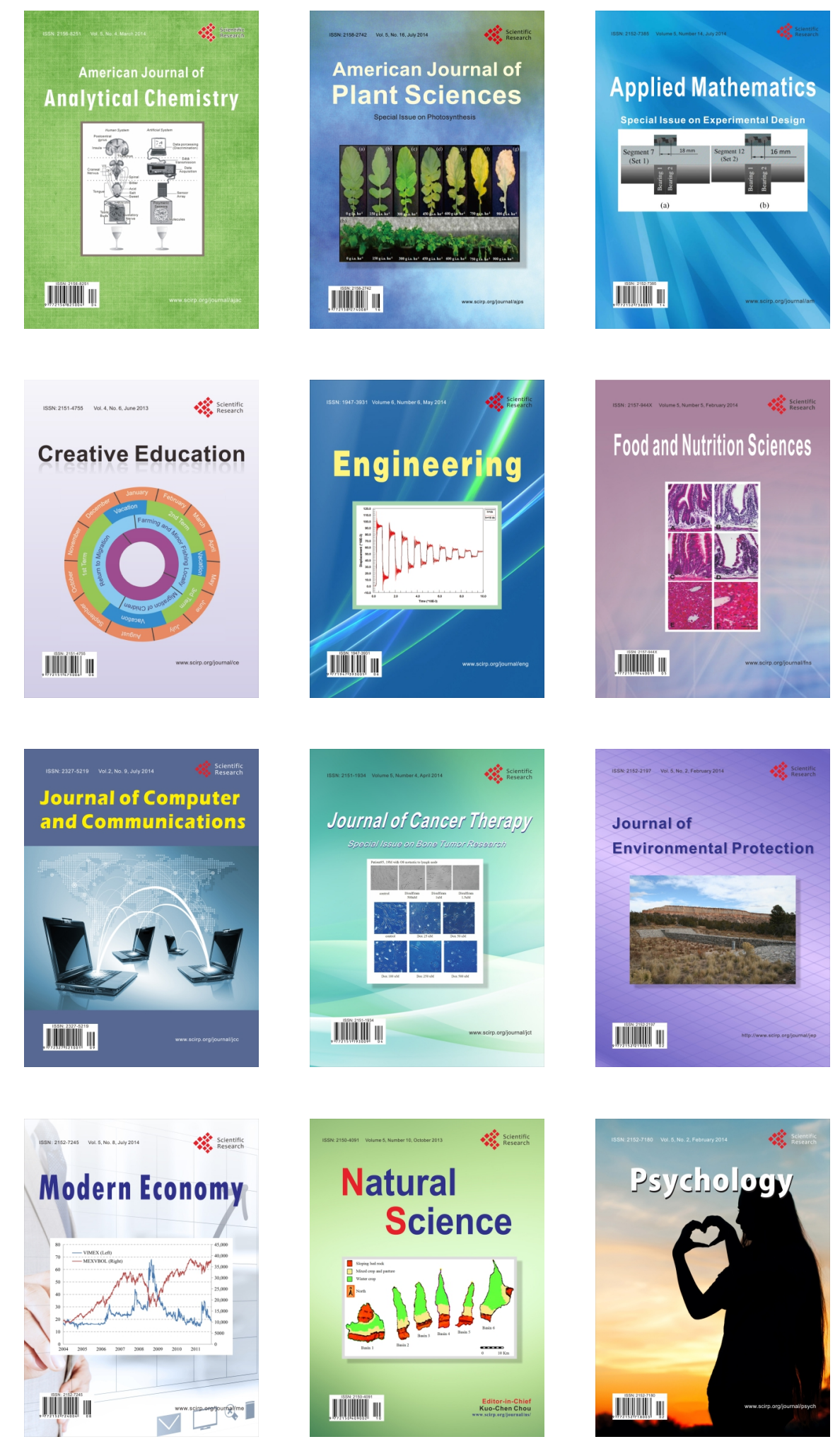